\title{
Determinants of Capital Structure within the Context of Corporate Governance in Egypt
}

\author{
Hanaa A. El-Habashy ${ }^{1,2}$ \\ ${ }^{1}$ Accounting Department, Faculty of Commerce, Menoufia University, Egypt \\ ${ }^{2}$ Department of Administrative \& Financial Sciences, University of Sharjah, UAE \\ Correspondence: Hanaa El-Habashy, University of Sharjah, UAE. E-mail: helhabashy@sharjah.ca.ae \& \\ hanaa82@hotmail.com
}

Received: April 19, 2018

Accepted: June 8, 2018

Online Published: June 30, 2018

doi:10.5539/ijbm.v13n8p26

URL: https://doi.org/10.5539/ijbm.v13n8p26

\begin{abstract}
This study aims to investigate the characteristics of corporate governance that impact the capital structure decisions in listed firms in Egypt, to test the efficiency of the research results conducted in the developed Western countries in an emerging economy. A sample of 240 observations from the most active non-financial companies collected in the period 2009-2014 was used for hypothesis testing. Multiple regression models (OLS) were used for data analysis. Seven variables are used in measuring the attributes of corporate governance; they are the managerial ownership, institutional shareholding, shares owned by a large block, board size, board composition, separation of $\mathrm{CEO} /$ Chair positions and audit type. Four ratios were calculated for measuring the capital structure, they are long-term and short-term debt to assets, total debt to assets and debt to equity. The results suggest that corporate governance attributes have a significant impact on the capital structure decisions of listed Egyptian companies. In addition, firm-specific factors such as profitability, tangibility, growth opportunities, corporate tax, firm size and non-debt tax shields influence the choice of capital structure in Egypt. The results showed the same relationship with what was obtained in developed Western countries. The paper offers some contribution in the literature and helps to understand the impact of corporate governance on Egypt's capital structure as an emerging economy.
\end{abstract}

Keywords: capital structure, corporate governance, board structure, ownership structure, Egypt, emerging economies.

\section{Introduction}

This study evaluates whether capital structure choices of Egyptian companies are influenced by corporate governance mechanisms. Corporate governance specify the variety of mechanisms that affect managers' decisions while separating ownership and control. Due to the global financial crisis, corporate governance has become an issue. Corporate governance theory's' prediction states that, agency costs and corporate value are influenced by financial leverage. The literature suggests several factors that determine their capital structure. The leading study carried out by Modigliani and Miller $(1958,1963)$ shows that the value of the company will be enhanced if the level of debt is high in perfect capital markets. They suggest that companies capitalize from the debt tax shield when using long-term debt to finance their business. However, using data for Jordan, Maghyereh (2005) concluded that perfect capital markets cannot exist then the company value is affected by gearing ratio and capital structure, as banks do not want to loan companies with high gearing ratios in capital structure because of the high risks related with high leveraged companies. Debt issuance can possibly be utilized as a governance tool to mitigate agency costs. Rocca (2007) declared that one of the main determinants of capital structure is corporate governance, accordingly corporate governance impact the choice of funding sources. As companies take governance decisions that aim to use financing to decrease the information asymmetry problem. The literature provides strong proof that the decisions of corporate capital structures are influenced by corporate governance mechanisms (Rocca, 2007; Driffield et al., 2007; Al-Najjar and Hussainey, 2009). The study aims to explore the impact of corporate governance mechanisms and firm specific characteristics on corporate capital structure decisions of the Egyptian listed corporations. Therefore, this study is aiming to answer the question which is: 
Q1:- What are the determinants of capital structure in Egyptian listed companies?

This study contributes to literature by offering evidence of the association between corporate governance and corporate financial leverage in Egypt. Although this relationship has been the topic of broad investigation in developed economies, limited study has been conducted to investigate this relation in the developing economies, and can be found less frequently in Middle Eastern countries, particularly in the Egyptian market. The results of this paper can be considered by investors and economists. As determining the factors that have derived capital structure decisions may also focus on developing a model of efficiency and good corporate governance practice. This paper uses the disclosure book of the most active companies' data for governance and corporate capital structure variables. The remainder of the study is structured as follows. Reviewing the existing literature to develop the hypotheses presented in the next section. Then the research methodology recognizes the data sources, variables definition, and models specification. Subsequently the empirical results and interpretations are provided. Finally, conclusions are offered in the last section.

\section{Literature Review}

The literature classifies corporate governance mechanisms into external and internal control mechanisms. While ownership and board structures are reflected as the internal corporate governance tools, the audit type is considered as the external control mechanism. In this section, the study reviews relevant literature that investigates the relation between leverage and corporate governance mechanisms to develop the hypotheses.

\subsection{Managerial Ownership and Capital Structure}

Trading off the agency cost of debt versus the benefit of debt achieves the most favorable capital structure (Jensen \& Meckling, 1976). The lower usage of debt reduces the threat of financial distress, subsequently, managerial shareholding and debt may be negatively related (Jensen 1986). The main objective of managers is to maximize the wealth of shareholders and achieve the highest performance of the company using fewer debt to prevent financial distress. Therefore there is a negative association between management ownership and leverage level (Berger et al., 2012). Sheikh and Wang, (2012); Brailsford et al., (2002) discover a negative association between managerial shareholding and gearing ratios. Ruan et al., (2011) examine the influence of managerial shareholders on the corporate performance through capital structure decisions, their results demonstrate a negative correlation between managerial shareholders and debt level when managerial shareholders are less than $18 \%$ or more than $46 \%$. While in the scope of managerial shareholders from $18 \%$ to $46 \%$, they found a positive relationship between them. Moreover, managerial opportunism may result from higher level of managerial shareholding and eventually leads to lower level of debt. Nevertheless, Myers (1977) developed an asymmetric information model that predicted that firms with a larger ratio of shares owned by the management had higher debt ratios. The main idea is that increased leverage allows managers to maintain a larger share of equity. As higher equity ownership reduces management well-being because of risk aversion. Therefore, high-quality corporate managers can point to this fact by increasing debt in the balance. Thus, its model predicts a positive association between management ownership and leverage. Moreover, Harris and Raviv (1988) models provide an additional theoretical basis for the hypothesis of a positive association between management ownership and leverage level. They debate that increasing debt may decrease the retaining control because of increased risk of bankruptcy, increased restrictions on debt covenants, and increased commitment to future cash payments. Masood (2014) indicated that using debt in capital structure to dominate and reduce the excessive use of management incentives and using managerial ownership to align the interests of managers with the interests of the other shareholders. Further, ownership concentration can be used as a pressure group to prevent managerial overruns.

Firm managers hold a large share of the company's shares and the special interests of managers, leading to fewer leverage level as managers seek to reduce the bankruptcy risk, or otherwise, the agency's benefits from using debt are replaced via managerial ownership. Hence, this study assumes that managerial ownership and leverage levels will be negatively related.

H1: There is a negative relationship between management ownership and leverage level.

\subsection{Institutional Investors and Capital Structure}

Previous literature has concentrated on the role of institutional owners as corporate monitors. The active monitoring hypothesis predicts that administrative opportunism can be reduced on a large scale by closely monitoring institutional investors to managers. Michaely \& Vincent (2013) explore the relation between institutional shareholding and corporate capital structure using data of U.S. firms. They found that institutional owners have a significant negative association with the leverage. In the same way, Smith (1996) found evidence 
compatible with the hypothesis of corporate monitoring as institutional owners can force managers to extremely emphasize on corporate performance and less on opportunistic or self-interest behavior that supports the active monitoring hypothesis. Al- Najjar and Taylor (2008); Hussainey and Aljifri (2012) find that debt ratio is negatively associated with institutional shareholding and indicate that firms with a large ratio of institutional investors are more likely to use fewer leverage levels which support the pecking order theory. However, Abdoli et al., (2012) provide evidence that there is positive statistically significant correlation between institutional investors and financial leverage because of their easy access to various funding sources. However, Hasan and Butt (2009) find insignificant relation between leverage ratios and the institutional shareholding. In line with the pecking order theory, this study assumes that companies reduce leverage level with increased institutional shareholdings, as they incline to issue more equity but not debt.

H2: There is a negative relationship between institutional investors and leverage level.

\subsection{Ownership Concentration and Capital Structure}

There is increasing evidence of the impact of the ownership structure on capital structure in emerging economies outside the Middle East. Cespedes et al., (2010) examine the influences of large shareholders on corporate capital structure choices in Latin American firms from 1996 to 2005, they show a U-shape non-linear relation between large shareholders and debt ratios. Similarly, Deesomsak et al., (2004) examine the capital structure sources of four Asian Pacific countries, they found that debt ratio is positively associated with ownership concentration in three of four countries, in which families control a significant share. Ownership concentration decreases agency costs of debt and consequently easy access for borrowing. In the same way, Driffield et al., (2007) establish a positive association between ownership concentration and leverage level in family companies in Indonesia, Malaysia and Thailand. Large shareholders prefer to use debt to avoid ownership dilution. While the large shareholders can decrease the agency cost, it can inspire the managers to rise profitability by debt financing. If this hypothesis holds true in describing the role of concentrated ownership, the association between large shareholders and leverage is supposed to be positive. Hence, this study assumes a positive correlation between concentrated ownership and leverage level.

H3: There is a positive relationship between concentrated ownership and leverage level.

\subsection{Board Size and Capital Structure}

Abor (2007); Hussainey and Aljifri, k (2012) Ganiyu and Abiodun (2012) and Agyei \& Owusu (2014) demonstrate a positive association between board size and debt ratios. Their results indicate that large boards pursue greater leverage to increase corporation value. Moreover, larger board membership may be more difficult to reach consensus in decision-making. The conflicts arising from large board size tend to weaken corporate governance resulting in increased leverage. This positive correlation shows that companies with larger board size are inclined to use more leverage to fund their activities instead of equities. Anderson (2004) also shows that the cost of financial leverage is mostly lower for large boards as lenders assume that these firms are efficiently controlled by varied experts. Therefore, debt financing is considered as an effective choice. However, Chitiavi et al., (2013); Uwuigbe (2013) indicate that debt-to-equity ratio is negatively significantly correlated with board size. This means that companies with larger board size generally preferred internal financing and have low leverage ratios. On the other hand, Hussainey and Aljifri, (2012) show insignificant relationship between board size and leverage in the UAE. Ajanthan (2013) show that none of the corporate governance attributes (Board Size, CEO duality, Board Composition) have a significant relationship with capital structures in Colombo Stock Exchange. This paper assumes that companies with large board sizes prefer debt financing instead of equity issuance to finance activities which lead to reduction in agency costs for these firms.

H4: There is a positive relationship between the board size and leverage level.

\subsection{Board composition and Capital Structure}

External managers play a dominant role in increasing the company's ability to gain recognition from corporate stakeholders. Consequently reducing uncertainty about the company and enhancing the company's ability to raise funds. The literature shows that a higher level of non-executive directors increases the leverage level. Jensen (1986) and Berger et al., (2012) detect that firms with higher financial leverage level have reasonably more non-executive directors, while firms with less non-executive directors have lower leverage level. Companies with a large share of non-executive members also appear to have easy access to loans, so they have high level of leverage (Al-Najjar \& Hussainey, 2011; Abor \& Biekpe, 2007). However, researchers like Abdoli et al., (2012) and Kuo et al. (2012) support the prediction that higher representation of non-executive members is followed by low leverage level and high market value of equity. They find a significant negative correlation between debt 
ratios and non-executive members on the board as managers apply low levels of debt when facing solid corporate governance. The likely reason is that non-executive members monitor managers more efficiently and effectively, hence managers have to get lower level of debt to achieve greater results. As directors may use debt issuance instead of issuing shares to fund their activities. However, this study adopts the prediction that increases in debt financing will be easier for such companies, therefore, assumes that Egyptian companies with higher level of non-executive directors increases the leverage level to benefit from the tax deductibility of interest payments

H5: There is a positive relationship between the presence of non-executive directors on the board and leverage level.

\subsection{CEO/Chair Duality and Capital Structure}

Governance rules indicate that the positions of CEO and the Chairman of the board must be filled by two different people to guarantee a balance of power. There are two competitive views on CEO / Chair duality based on whether the company is served by strong leadership (stewardship theory), or through effective monitoring (agency theory). Fama and Jensen (1983) support the separation of the CEO and the Chair because duality will decrease the supervision of the company's board of directors, leading to an increase in agency costs. Accordingly, separating the positions of the Chairman and CEO may lead to better company decisions and thus better performance. The empirical results on the association between duality and capital structure is mixed. While Abor and Biekpe (2007) and Amarjit et al. (2012) found a positive correlation between debt ratios and CEO duality, Ganiyu and Abiodun (2012) found a negative relationship between such attributes. If the study assumes that separation empowers the board of directors to apply more control over CEO decisions through effective monitoring and thereby optimize the debt acquired by managers, it can be proposed that:

H6: There is a positive relationship between the separation of the CEO and the Chair and leverage level.

\subsection{Audit type and Capital Structure}

Bharath et al. (2009) show that asymmetric information positively impact the financial leverage. They show that firms with high levels of asymmetric information can be inclined to use debt to fund their activities instead of equity. Further, they offered the first indication that asymmetric information influences the corporate capital structure choices of US companies. In addition, the results of Abad et al. (2017) show that the information asymmetry among the managers and investors are decreased when the financial statements are audited by one of the big 4 firms, where investors can assume enhanced future earnings on the stock exchange. Consequently, this paper considers the effect of the information environment on the corporate capital structure for the Egyptian companies. Audit type is used as a proxy of the firm's information environment. The audit type is measured as a dummy variable equals 1 if the audit firm is one of the big 4 firms and 0 if otherwise. Consequently, this paper assumes a positive correlation between audit type and the financial leverage, hence it can be proposed that:

H7: There is a positive relationship between audit type and leverage level.

\section{Research Methodology}

The study examines the association between capital structure and corporate governance for Egyptian firms. In this section, the sample and data sources, variables definition, and model specification are indicated.

\subsection{Sample and Data Sources}

This paper uses data of the most active companies in the Egyptian Stock Market covering the different sectors of companies provided by the Disclosure Book issued by the Egyptian Exchange (EGX) in Cairo. The disclosure book provides consolidated information about the company, including basic information, board of directors, shareholding structure, latest three-year financial figures and ratios as well as the latest corporate actions and material events for each company. The data spans the period from 2009-2014 as the availability of data. Data on financial companies are not included as these companies are totally different from non-financial companies, and some attributes may not be comparable between financial and other companies. The samples of companies are selected based on the accessibility of data. The study uses the disclosure book of the most active companies' data for leverage and governance variables. The banking and insurance sectors were excluded, consequently, only corporate annual reports of the most active non-financial firms were collected. Hence, the final data has 240 firm-years observations.

\subsection{Variables Definition}

\subsubsection{Independent Variables}

Seven variables were calculated as measures of corporate governance quality. They are top management 
shareholding, institutional shareholding, proportion of shares owned by a large block, board size, ratio of non-executive directors, $\mathrm{CEO} /$ Chair duality and audit type.

\subsubsection{Dependent Variables}

In previous research, the capital structure proxy has yet to be agreed upon, Hussainey and Aljifri (2012) and Abdul-Qadir et al. (2015) used total debt to equity as a proxy for capital structure. While Purag and Abdullah (2016); Wahap and Ramli (2014); Michaely amd Vincent (2013); Sheikh and Wang, (2012) employed long-term and short-term debt to assets and total debt to assets as a proxy for capital structure. In this study four ratios to measure capital structure were calculated namely long-term debt to assets (LTDA), short-term debt to assets (STDA), total debt to assets (TD) and debt to equity (DE). This study uses data being disclosed in the financial statements for calculating capital structure variables. Codes and variables measurements are summarized in Table (1).

Table 1. Description of variables

\begin{tabular}{|c|c|c|}
\hline Symbol & Definition & Measurement \\
\hline \multicolumn{3}{|c|}{ Independent variables:- Governance variables } \\
\hline ManOwn & Managerial Ownership & Ratio of the company's shares owned by the top management. \\
\hline INST & Institutional Ownership & $\begin{array}{l}\text { Ratio of shares owned by institutional shareholders, including the Egyptian } \\
\text { government. }\end{array}$ \\
\hline OWCO & Ownership Concentration & Ratio of shares owned by the largest shareholders \\
\hline BSIZE & Board Size & Number of directors. \\
\hline BINDEP & Board Independence & Ratio of non-executive directors on the board. \\
\hline DUAL & CEO/Chair Duality & $\begin{array}{l}\text { A dummy variable equals } 0 \text { if the positions of CEO and the Chairman of the } \\
\text { board filled by the same person and } 1 \text { otherwise. }\end{array}$ \\
\hline AUDIT & Audit type & $\begin{array}{l}\text { A dummy variable equals } 1 \text { if the audit firm is one of the big } 4 \text { firms and } 0 \text { if } \\
\text { otherwise. }\end{array}$ \\
\hline \multicolumn{3}{|c|}{ Dependent variables:- Capital Structure variables } \\
\hline LTDA & Long-term debt & Long term debt / total assets. \\
\hline STDA & Short-term debt & Short term debt / total assets. \\
\hline TDA & Total debt & Total debt / total assets. \\
\hline $\mathrm{DE}$ & Debt to equity & Total debt / equity. \\
\hline \multicolumn{3}{|c|}{ Control variables - the determinants of capital structure in the literature } \\
\hline SIZE & Firm Size & Total Assets. \\
\hline ROA & Profitability & Net income / sales. \\
\hline TANG & Tangibility & Net fixed assets / total assets. \\
\hline Tobin's Q & Growth prospects & $\begin{array}{l}\text { The market value of shares and book value of debt divided by the book value } \\
\text { of total assets }\end{array}$ \\
\hline TAX & Corporate taxes & Company tax \\
\hline NDT & Non-debt tax shields & Depreciation / total assets \\
\hline
\end{tabular}

\subsubsection{Control Variables}

Al-Najjar and Taylor (2008) investigate the association between the capital structure and corporate governance in Jordan, they have shown that the Jordanian firms have established the same relations with what has been achieved in developed Western economies. They pointed out that capital structure is effected by firm-specific factors such as profitability, tangibility, growth opportunities, corporate tax, firm size and non-debt tax shields. Thus, this study uses firm specific characteristics that are recognized in the literature to have an impact on the capital structure decisions as follows.

\subsubsection{Firm Size}

The relation between firm size and leverage is debated in two diverse situations. Ergotis et al. (2007); Tomak, (2013) support the positive association between firm size and leverage levels. They argue that larger firms may contract loans on more favorable terms which allow them to get more debt at lower interest rates. As larger firms are less risky and less prone to bankruptcy than smaller companies, debt providers are willing to lend them more financings. The positive relation between firm size and capital structure support agency theory and trade-off 
theory predicts. In the other context, Wahap and Ramli (2014) find negative correlation between firm size and the long term debt ratio. The negative association between firm size and capital structure is inconsistent with agency theory. Some studies find insignificant influence of size on capital structure (Ghazouani, 2013). Consistent with agency theory and trade-off theory, this study assumes a positive correlation between firm's size and gearing ratio in Egyptian firms.

\subsubsection{Profitability}

Pecking order theory assumes that high-profit firms borrow less as there is no need for external funds and that less-profitable firms borrow debt because of insufficient internal funds for their activities and investments (Abdul-Qadir et al., 2015). Purag amd Abdullah (2016); Delcoure (2007); and Brailsford et al., (2000) demonstrate a negative correlation between profitability and capital structure choice. However, some practical researches detect a positive relation between leverage and profitability (Zerriaa \& Noubbigh, 2015). They attribute this observation to the trade-off theory, as firms with high profitability are more likely to have higher leverage as they have more income to shield from taxes. Moreover, Bauer, (2004) argue that free cash flow theory predicates that high profitable firms are more inclined to use debt to discipline managers and persuade them to pay out cash rather than using money on inefficient projects. In line with the pecking order theory, this paper predicts a negative correlation between profitable firms and leverage level in Egypt.

\subsubsection{Tangibility}

There is a consensus in previous studies that the tangible assets are related to the leverage. Gwatidzo and Ojah (2009); Booth et al., (2001); Friend and Lang (1988) showed a significant positive correlation between gearing ratios and tangible assets for companies in their sampled countries. Moreover, in case of bankruptcy, a higher amount of assets tangibility can increase the salvage value of the company's assets. So the providers of financing are willing to lend firms that have a high level of tangibility. However, Sheikh and Wang (2011); Abor and Biekpe (2005) demonstrate a significant negative correlation between such variables in their sampled countries. This result is attributed to higher operating risk correlated with a higher share of fixed assets. Generally, the preceding research provide support for the positive correlation between asset tangibility and the gearing ratios. However, the negative correlation is detected only in exceptional conditions. This is because of the effect of the institutional environment on capital loan providers. The proportion of net fixed assets to total assets is used in measuring the tangibility.

\subsubsection{Growth Prospects}

Signaling and pecking order theories support a positive correlation between firm growth and debt ratios. Al Najjar (2011) discovers a positive correlation between debt ratios and growth for Jordanian firms. Al Najjar results support signaling theory, tax based theory and pecking order theories. This result is opposing to the expectations of Myers (1977) indicates that growth companies in Jordan prefer to fund their activities with debt. As companies with intangible growth estimates may avoid debt to alleviate the possible shortage of investment related to financial distress. Ngugi (2008); Eriotis et al., (2007) agree with this perspective. However, using data for companies in European countries, Delcoure (2007) failed to find a significant correlation between growth opportunities and gearing ratios. The market value of shares and debt divided by the book value of assets is used to measure growth prospects. Consistent with the signaling and pecking order theories, this paper predicts a positive association between growth and gearing ratio in Egyptian firms.

\subsubsection{Corporate Taxes}

The trade-off theory indicates that a firm's leverage is determined by taxes, bankruptcy costs, and agency conflicts. Presence of debt in the capital structure of the company reduces its tax liabilities and raises after-tax cash flow existing to capital providers. The empirical evidence is mixed Graham (2001); Homaifar, et al., (1994) show that corporate taxes impact leverage in a positive manner. However, Abor and Biekpe (2005) find that taxes are negatively correlated with financial leverage. Some rehearses show statistically insignificant relation between tax and leverage, e.g. Gwatidzo and Ojah (2009) and Ngugi (2008) locate insignificant relationships for Kenya and South Africa respectively. It would be assumed that the relationship between taxes and debt ratios may be positive.

\subsubsection{Non-debt Tax Shield}

The tax based theory expects that companies are willing to use debt financing because of the tax deductibility of interest payments. The corporate' marginal savings from an additional unit of debt reduces with increasing non-debt tax shields. This is due to the possibility of increased bankruptcy with debt (DeAngelo and Masulis 1980). Accordingly, under the theory of trade-off, one assumes a negative relation between financial leverage 
and non-debt tax shields. The empirical evidence is mixed. In this study, the non-debt tax shields is defined as the percentage of depreciation to total assets (Brailsford et al., 2002).

\subsection{Model Specification}

To investigate the correlation between corporate governance mechanisms and capital structure choices, this study use the following models (Regression equation) to test research hypotheses.

Model $_{1}$ : Long-term debt to assets $=\mathrm{f}$ (Governance components, Control variables)

$$
\begin{array}{r}
\text { LTDAit }=\beta_{0}+\beta_{1} \text { ManOwn it }+\beta_{2} \text { INSTit }+\beta_{3} \text { OWCOit }+\beta_{4} \text { BSIZEit }+\beta_{5} \text { BINDEPit }+\beta_{6} \text { DUALit }+\beta_{7} \text { AUDITit }+ \\
\beta_{8} \text { SIZEit }+\beta_{9} \text { ROAit }+\beta_{10} \text { TANGit }+\beta_{11} \text { TobinQit }+\beta_{12} \text { TAXit }+\beta_{13} \text { NDTit }+ \text { eit }
\end{array}
$$

Model $_{2}$ : Short-term debt to assets $=\mathrm{f}$ (Governance components, Control variables)

$$
\begin{array}{r}
\text { STDAit }=\beta_{0}+\beta_{1} \text { ManOwn it }+\beta_{2} \text { INSTit }+\beta_{3} \text { OWCOit }+\beta_{4} \text { BSIZEit }+\beta_{5} \text { BINDEPit }+\beta_{6} \text { DUALit }+\beta_{7} \text { AUDITit }+ \\
\beta_{8} \text { SIZEit }+\beta_{9} \text { ROAit }+\beta_{10} \text { TANGit }+\beta_{11} \text { TobinQit }+\beta_{12} \text { TAXit }+\beta_{13} \text { NDTit }+ \text { eit }
\end{array}
$$

Model $_{3}$ : Total debt to assets $=\mathrm{f}($ Governance components, Control variables $)$

$$
\begin{array}{r}
\text { TDAit }=\beta_{0}+\beta_{1} \text { ManOwn it }+\beta_{2} \text { INSTit }+\beta_{3} \text { OWCOit }+\beta_{4} \text { BSIZEit }+\beta_{5} \text { BINDEPit }+\beta_{6} \text { DUALit }+\beta_{7} \text { AUDITit }+ \\
\beta_{8} \text { SIZEit }+\beta_{9} \text { ROAit }+\beta_{10} \text { TANGit }+\beta_{11} \text { TobinQit }+\beta_{12} \text { TAXit }+\beta_{13} \text { NDTit }+ \text { eit }
\end{array}
$$

Model $_{4}$ : Debt to equity $=\mathrm{f}$ (Governance components, Control variables)

$$
\begin{array}{r}
\text { DEit }=\beta_{0}+\beta_{1} \text { ManOwn it }+\beta_{2} \text { INSTit }+\beta_{3} \text { OWCOit }+\beta_{4} \text { BSIZEit }+\beta_{5} \text { BINDEPit }+\beta_{6} \text { DUALit }+\beta_{7} \text { AUDITit }+ \\
\beta_{8} \text { SIZEit }+\beta_{9} \text { ROAit }+\beta_{10} \text { TANGit }+\beta_{11} \text { TobinQit }+\beta_{12} \text { TAXit }+\beta_{13} \text { NDTit }+ \text { eit }
\end{array}
$$

Variable definitions are shown in Table (1). Coefficient $\beta 1$ through $\beta 7$ represent the coefficient estimate for the individual firm governance components analysis of the assumed relationship, while $\beta 8$ through $\beta 14$ refers to the coefficient estimates for the control variables proposed by previous studies as influences of capital structure. eit $=$ error term.

Table 2. Descriptive statistics

\begin{tabular}{llllll}
\hline & Mean & Median & Std. Deviation & Min & Max \\
\hline ManOwn & 0.07 & 0.00 & 0.14 & 0.00 & 0.66 \\
INST & 0.21 & 0.06 & 0.28 & 0.00 & 0.92 \\
OWCO & 0.38 & 0.33 & 0.23 & 0.00 & 0.92 \\
BSIZE & 10.72 & 11 & 3.74 & 5 & 21 \\
BINDEP & 0.83 & 0.89 & 0.13 & 0.44 & 1 \\
DUAL & 0.23 & 0 & 0.42 & 0 & 1 \\
AUDIT & 0.51 & 1 & 0.5 & 0 & 1 \\
SIZE & 8049 & 2053 & 14454 & 48 & 59300 \\
ROA & 0.07 & 0.06 & 0.08 & -0.10 & 0.34 \\
TANG & 0.32 & 0.32 & 0.23 & 0 & 0.83 \\
Tobin's Q & 0.01 & 0.01 & 0.01 & 0.00 & 0.05 \\
TAX & 125.5 & 16 & 309.3 & 0 & 2013 \\
NDT & 0.01 & 0 & 0.02 & 0 & 0.14 \\
LTDA & 0.06 & 0.02 & 0.11 & 0 & 0.67 \\
STDA & 0.08 & 0.03 & 0.10 & 0.00 & 0.40 \\
TDA & 0.14 & 0.08 & 0.15 & 0 & 0.67 \\
DE & 0.21 & 0.00 & 0.60 & 0.00 & 4.00 \\
\hline
\end{tabular}


Table 3. Pearson correlation matrix

\begin{tabular}{|c|c|c|c|c|c|c|c|c|c|c|c|c|c|c|c|c|c|c|}
\hline & & 1 & 2 & 3 & 4 & 5 & 6 & 7 & 8 & 9 & 10 & 11 & 12 & 13 & 14 & 15 & 16 & 17 \\
\hline 1. & ManOwn & 1 & & & & & & & & & & & & & & & & \\
\hline \multirow{2}{*}{2.} & INST & $-.315^{\cdots \cdots}$ & 1 & & & & & & & & & & & & & & & \\
\hline & & .000 & & & & & & & & & & & & & & & & \\
\hline \multirow{2}{*}{3.} & owco & -.008 & $.197^{* *}$ & 1 & & & & & & & & & & & & & & \\
\hline & smer & .907 & .002 & & & & & & & & & & & & & & & \\
\hline \multirow{2}{*}{4.} & & .017 & $.380^{* * *}$ & $-.217^{\cdots *}$ & 1 & & & & & & & & & & & & & \\
\hline & Drizo & .794 & .000 & .001 & & & & & & & & & & & & & & \\
\hline \multirow{2}{*}{5.} & PDUPFP & -.009 & $.181^{* * *}$ & $-.333^{\cdots *}$ & $.363^{\cdots \cdots}$ & 1 & & & & & & & & & & & & \\
\hline & BINDEP & .893 & .005 & .000 & .000 & & & & & & & & & & & & & \\
\hline \multirow{2}{*}{6.} & Dugl & $-.122^{\circ}$ & -.016 & .028 & .071 & .069 & 1 & & & & & & & & & & & \\
\hline & Dudi & .059 & .801 & .663 & .274 & .291 & & & & & & & & & & & & \\
\hline \multirow{2}{*}{7.} & HDTT & .064 & $-.209^{\cdots \cdots}$ & -.100 & -.022 & .045 & $.166^{\circ}$ & 1 & & & & & & & & & & \\
\hline & NODHT & .329 & .001 & .129 & .742 & .497 & .011 & & & & & & & & & & & \\
\hline \multirow{2}{*}{8.} & Sim & -.073 & -.035 & -.014 & -.002 & .064 & $.165^{\circ}$ & $.160^{\circ}$ & 1 & & & & & & & & & \\
\hline & & .263 & .592 & .824 & .981 & .324 & .011 & .014 & & & & & & & & & & \\
\hline \multirow{2}{*}{9.} & POA & -.097 & $.396^{* *}$ & $-.124^{*}$ & $.540^{\cdots \cdots}$ & $.280^{\cdots *}$ & -.004 & $-.109^{*}$ & $-.142^{* *}$ & 1 & & & & & & & & \\
\hline & KOA & .134 & .000 & .056 & .000 & .000 & .953 & .098 & .028 & & & & & & & & & \\
\hline \multirow{2}{*}{\multicolumn{2}{|c|}{ 10. TANG }} & -.037 & -.082 & $.112^{\circ}$ & .089 & $.258^{\cdots *}$ & .060 & .001 & -.031 & .054 & 1 & & & & & & & \\
\hline & & .572 & .203 & .084 & .171 & .000 & .351 & .989 & .628 & .408 & & & & & & & & \\
\hline \multirow{2}{*}{\multicolumn{2}{|c|}{ 11. Tobin's Q }} & -.102 & $.327^{* * *}$ & .004 & $.147^{* *}$ & .001 & .019 & -.055 & -.029 & $.497^{\cdots \cdots}$ & -.236 & 1 & & & & & & \\
\hline & & .117 & .000 & .954 & .023 & .992 & .764 & .400 & .657 & .000 & .000 & & & & & & & \\
\hline \multirow{2}{*}{\multicolumn{2}{|c|}{ 12. TAX }} & $-.140^{* *}$ & -.051 & $.221^{\cdots}$ & -.058 & $-.163^{* \prime}$ & .078 & $.307^{* * *}$ & .009 & -.023 & $.172^{\cdots *}$ & .078 & 1 & & & & & \\
\hline & & .030 & .429 & .001 & .369 & .012 & .229 & .000 & .891 & .722 & .008 & .227 & & & & & & \\
\hline \multirow{2}{*}{\multicolumn{2}{|c|}{ 13. NDT }} & $.148^{\circ "}$ & .031 & $.256^{\circ}$ & $-.148^{* \prime}$ & -.036 & -.001 & $.238^{* *}$ & -.008 & $-.127^{\circ}$ & $.117^{\circ}$ & -.037 & $.636^{\cdots *}$ & 1 & & & & \\
\hline & & .022 & .634 & .000 & .022 & .574 & .984 & .000 & .902 & .050 & .071 & .571 & .000 & & & & & \\
\hline \multirow{2}{*}{\multicolumn{2}{|c|}{ 14. TDA }} & $.3077^{\cdots \cdots}$ & $-.359^{\cdots \cdots}$ & $.179^{9 \cdots}$ & $-.198^{\cdots \cdots}$ & -.098 & .098 & $.180^{\cdots \cdots}$ & -.097 & $-.308^{* * *}$ & $.416^{* \cdots}$ & $-.136^{*}$ & $.427^{\cdots \cdots}$ & $.321^{\cdots *}$ & 1 & & & \\
\hline & & .000 & .000 & .005 & .002 & .132 & .129 & .006 & .134 & .000 & .000 & .035 & .000 & .000 & & & & \\
\hline \multirow{2}{*}{\multicolumn{2}{|c|}{ 15. DE }} & $-.178^{\cdots \cdots}$ & $-.215^{\cdots *}$ & .106 & $-.157^{*}$ & -.084 & $.127^{* *}$ & $.269^{\cdots * *}$ & -.005 & $-.189^{\circ \cdots}$ & $.384^{\cdots *}$ & .016 & $.739^{\circ * *}$ & $.472^{\cdots \cdots}$ & $.572^{\cdots \cdots}$ & 1 & & \\
\hline & & .006 & .001 & .103 & .015 & .196 & .049 & .000 & .942 & .003 & .000 & .802 & .000 & .000 & .000 & & & \\
\hline \multirow{2}{*}{\multicolumn{2}{|c|}{ 16. LTDA }} & -.085 & $-.207^{\cdots \cdots}$ & $.262 \cdots$ & $-.108^{*}$ & $-201 \cdots$ & $.111^{\circ}$ & $.163^{* *}$ & -.032 & $-194^{* * *}$ & $.366^{\circ *}$ & -.005 & $.720^{\cdots *}$ & $.424 \cdots$ & $.726^{\circ *}$ & $.736^{\circ \cdots}$ & 1 & .031 \\
\hline & & .192 & .001 & .000 & .096 & .002 & .087 & .013 & .623 & .003 & .000 & .941 & .000 & .000 & .000 & .000 & & .637 \\
\hline \multirow{2}{*}{\multicolumn{2}{|c|}{ 17. STDA }} & $.533^{\cdots \cdots}$ & $-309^{\cdots \cdots}$ & -.008 & $-.177^{\cdots+\cdots}$ & .065 & .030 & .096 & $-.108^{\circ}$ & $-249^{* *}$ & $.229^{\cdots *}$ & $-193^{\cdots *}$ & $-.117^{\circ}$ & .032 & $.709^{\circ \cdots}$ & .077 & .031 & 1 \\
\hline & & .000 & .000 & .907 & .006 & .318 & .648 & .142 & .094 & .000 & .000 & .003 & .069 & .625 & .000 & .236 & .637 & \\
\hline
\end{tabular}

\section{Empirical Results}

\subsection{Descriptive Statistics}

Mean, median, standard deviation, minimum, and maximum for the variables in the data sample of this study are presented in Table (2). The mean for size of the board of directors is 10.72 members with maximum of 21 members and minimum of 5 members. The average of the sample is characterized by the following mean values: non-executives represent 0.83 of the board, and separation of CEO/Chair positions of 0.23 . On the ownership side, the share of institutional shareholders ranges from 0 to 0.92 with an average of about 0.21 and a standard deviation of 0.28. In accordance with the average, it appears that Egyptian listed firms having reasonable proportion of institutional shareholders. The mean of largest block-holder percentage ranges from 0.1 to 0.92 with an average of 0.38 . The average of top management ownership proportion ranges from 0 to $66 \%$ with an average ratio of $7 \%$ and a standard deviation of $14 \%$. Also, the mean of the firms' total debt to assets ranges from 0 to $67 \%$ with average ratio of $14 \%$. The firms' debt to equity ranges from 0 to $400 \%$ and average ratio of $21 \%$.

\subsection{Correlation}

Table 3 shows the correlation coefficients for the gearing, governance and control variables. Correlation coefficients are presented above and the p-values are presented below. Significant coefficients at the 1\%, 5\%, and $10 \%$ levels are noted by $* * *, * *$ and $*$, respectively. 
Table 4. Collinearity analysis

\begin{tabular}{lll}
\hline & Collinearity \\
& Tolerance & VIF \\
\hline ManOwn & .630 & 1.587 \\
INST & .482 & 2.075 \\
OWCO & .627 & 1.596 \\
BSize & .489 & 2.045 \\
BINDEP & .638 & 1.567 \\
Dual & .922 & 1.085 \\
AUDIT & .789 & 1.268 \\
Size & .912 & 1.097 \\
ROA & .476 & 2.102 \\
TANG & .735 & 1.361 \\
Tobin's Q & .616 & 1.624 \\
TAX & .408 & 2.453 \\
NDT & .438 & 2.284 \\
\hline
\end{tabular}

\subsection{Regression Analysis and Discussion}

The tolerance values for each variable is obtained using (1-R2) as shown in table 4. As none of the values exceed 0.10 , thus no risk of multi-colinearity between the independent variables. Moreover the VIF of the independent variables do not exceed 10, which indicates that there is no multi-colinearity between these variables. The results of the regression analysis of the models developed for this study are represented in Table (5). The models analyze the impact of individual firm governance components on the leverage ratio dimensions explored in this study. The objective is to determine the governance component that drives specific gearing dimensions. To exam these impacts, this study repeats the empirical analysis in four different OLS regression models called Models (1 - 4), where the dependent variable in each model are replaced with one of the capital structure dimensions. F-statistics on all models are more than 5 and significant at the level of 0.01 and have high explanatory powers (see Table 6).

Beta coefficients and $t$ statistics are shown in Table 5 for the independent and control variables. The findings demonstrate that managerial ownership has positive significant correlation with short term debt, total debt ratio and debt to equity at the 0.01 level. Accordingly $\mathrm{H} 1$ is rejected. This result is in agreement with the asymmetric information model and the results of Driffield et al., 2007; Harris and Raviv (1988). The finding supports the theoretical expectation that in Egypt, firms with high managerial ownership are inclined to prefer leverage that allows managers to maintain a greater share of equity. The main idea is that increased leverage allows managers to maintain a larger share of equity, thus, managers can point to this fact by increasing debt.

Table 5. Governance-Capital structure relation

\begin{tabular}{|c|c|c|c|c|c|c|c|c|c|c|c|c|c|}
\hline & $\begin{array}{l}\text { Exp. } \\
\text { sig. }\end{array}$ & $\begin{array}{l}\text { LTDA } \\
\text { Coefficient } \\
\text { Beta } \\
\end{array}$ & $\begin{array}{l}\text { Sig. } \\
t\end{array}$ & P-value & $\begin{array}{l}\text { STDA } \\
\text { Coefficient } \\
\text { Beta } \\
\end{array}$ & $\begin{array}{l}\text { Sig. } \\
t \\
\end{array}$ & $P$-value & $\begin{array}{l}\text { TDA } \\
\text { Coefficient } \\
\text { Beta } \\
\end{array}$ & $\begin{array}{l}\text { Sig. } \\
t\end{array}$ & P-value & $\begin{array}{l}\text { DE } \\
\text { Coefficient } \\
\text { Beta } \\
\end{array}$ & $\begin{array}{l}\text { Sig. } \\
t\end{array}$ & P-value \\
\hline (Constant) & & -.001 & -.041 & .967 & .034 & .808 & .420 & .033 & .617 & .538 & -.137 & -.772 & .441 \\
\hline ManOwn & - & -.021 & -.431 & .667 & .568 & 8.976 & .000 & .371 & 6.783 & .000 & .126 & -2.767 & .006 \\
\hline INST & - & -.173 & -3.113 & .002 & .052 & .714 & .476 & -.086 & -1.376 & .170 & -.150 & -2.885 & .004 \\
\hline OWCO & + & .077 & 1.586 & .114 & -.066 & -1.036 & .302 & .009 & .171 & .864 & -.090 & -1.979 & .049 \\
\hline BSize & + & .118 & 2.136 & .034 & -.224 & -3.123 & .002 & -.069 & -1.117 & .265 & .000 & .008 & .994 \\
\hline BINDEP & + & -.076 & -1.586 & .114 & .093 & 1.477 & .141 & .009 & .161 & .872 & .003 & .059 & .953 \\
\hline Dual & + & .044 & 1.088 & .278 & .097 & 1.855 & .065 & .097 & 2.134 & .034 & .042 & 1.118 & .265 \\
\hline AUDIT & + & -.068 & -1.574 & .117 & .078 & 1.373 & .171 & .005 & .101 & .920 & .021 & .526 & .599 \\
\hline Size & + & -.061 & -1.516 & .131 & -.120 & -2.278 & .024 & -.124 & -2.732 & .007 & -.058 & -1.540 & .125 \\
\hline ROA & - & -.272 & -4.866 & .000 & -.191 & -2.626 & .009 & -.321 & -5.092 & .000 & -.263 & -5.031 & .000 \\
\hline TANG & + & .296 & 6.593 & .000 & .291 & 4.977 & .000 & .406 & 8.015 & .000 & .325 & 7.725 & .000 \\
\hline TobinsQ & + & .177 & 3.608 & .000 & .039 & .614 & .540 & .151 & 2.725 & .007 & .214 & 4.643 & .000 \\
\hline TAX & + & .654 & 10.848 & .000 & -.020 & -.256 & .798 & .447 & 6.568 & .000 & .601 & 10.620 & .000 \\
\hline NDT & - & -.033 & -.563 & .574 & -.135 & -1.775 & .077 & -.115 & -1.749 & .082 & .070 & 1.288 & .199 \\
\hline
\end{tabular}

Institutional ownership has negative significant correlation with long term debt and total debt to equity. The 
results show that companies with a large percentage of institutional shareholders have a lower ratio of debt to equity for financing, particularly long term debt. Therefore $\mathrm{H} 2$ is accepted. The findings verify the pecking order theory and in agreement with the findings of Hussainey and Aljifri (2012) Yaseen, and Al-Amarneh (2015).

The study shows that the ratio of large block holders is insignificantly positive with LTDA and TDA, insignificantly negative with STDA and insignificantly negative with DE at the level 0.05 , which indicates that the firms with high percentage of block holders tend to use less leverage. Accordingly the results refuse H3. The findings are consistent with the active monitoring hypothesis, while are opposite to the findings of Deesomsak et al., (2004) and Driffield et al. (2007).

Regarding board size, the findings establish a significant positive association with long term debt, while there is a significant negative correlation with short term ratio at the 0.05 and 0.01 levels respectively. Accordingly $\mathrm{H} 4$ is rejected. The findings indicate that a large board size leads to reduced short-term debt and increased long-termdebt. This findings are inconsistent with the trade-off theory and the results of Hussainey and Aljifri, k (2012); Ganiyu and Abiodun (2012) and Agyei \& Owusu (2014) who find a positive relation.

The results show that non-executive directors and audit type have an insignificant effect on all capital structure variables. Therefore the results reject $\mathrm{H} 5$ and H7. These results can be interpreted as the absence of effective application of appropriate corporate governance principles in listed firms in Egypt.

The CEO's duality is found positive significantly with TDA and STDA, while it is insignificantly positive with DE and LTDA, accordingly $\mathrm{H} 6$ is partially accepted. The results support the trade-off theory and the findings of Abor and Biekpe (2007) and Amarjit G. et al. (2012) that provide a positive correlation between gearing ratios and CEO duality.

The firm size has a negative significant influence on TDA and STDA, while it has an insignificant negative impact on DE and LTDA. The negative correlation between firm size and capital structure is inconsistent with what agency theory and trade-off theory predict. It is shown that larger companies in Egypt are more likely to be less diversified in their debt management. These findings are in agreement with the pecking order theory, as companies prefer internal resources when available. This is consistent with the findings of Wahap and Ramli (2014).

Profitability ratio has a negative significant influence on the capital structure variables. While tangibility is positively significant with the capital structure variables. The results are in agreement with trade-off and agency theories. The results verify the findings of Al Najjar (2011); Gwatidzo and Ojah (2009); Booth et al., (2001).

Growth ratio and corporate taxes have a positive significant influence on long term debt, total debt to assets and debt to equity. The results prove pecking order theory and bankruptcy theory.

Non-debt tax shields have a significant negative influence on short-term debt and total debt while having an insignificant positive influence on debt to equity and insignificant negative effect with long term debt. The findings partially support trade-off theory.

Table 6. Models summary

\begin{tabular}{lllll}
\hline & $\begin{array}{l}\text { Model } 1 \\
\text { LTDA }\end{array}$ & $\begin{array}{l}\text { Model 2 } \\
\text { STD } \boldsymbol{A}\end{array}$ & $\begin{array}{l}\text { Model 3 } \\
\text { TDA }\end{array}$ & $\begin{array}{l}\text { Model 4 } \\
\text { DE }\end{array}$ \\
\hline F & 34.995 & 13.616 & 23.787 & 42.087 \\
R2 & 0.674 & 0.446 & 0.584 & 0.713 \\
Adjusted R2 & 0.655 & 0.413 & 0.560 & 0.696 \\
p-value & 0.000 & 0.000 & 0.000 & 0.000 \\
\hline
\end{tabular}

The results of the regression analysis summarized in Table 6 shows that corporate governance contributes significantly to the capital structure. The models predict that $65.5 \%, 41.3 \%, 56 \%, 69.6 \%$, of variation in loan selection can be clarified through models (1-4) respectively.

\section{Conclusion}

This study empirically investigated the effect of corporate governance and control variables suggested by earlier studies on capital structure decisions in Egypt as an emerging market. The data spans the period from 2009-2014, the final data which has 240 firm-year observations, was collected to test the hypotheses. Multiple regression models were used for data analysis. 
Regarding the ownership structure, the findings show that the management ownership played a significant role in determining corporate capital structure decisions. This result supports the asymmetric information model and is against trading off theory. Additionally, the results appear that the ratio of block share and institutional share are negatively significant with debt to equity, which is partially against corporate governance philosophy. The findings are in agreement with the active monitoring hypothesis as the block holders have the motive to monitor managers to defend their investments by favoring equity issuance instead of debt issuance.

Regarding the board structure, the study found that, firms that have a separating of the roles of the Chairman and CEO are positively significantly correlated with short term debt and total debt to asset. This result is consistent with regulation and agency theory. Further, the finding shows that non-executive directors have an insignificant effect on leverage level. Moreover, large board size leads to short-term debt reduction and long-term debt increases. Consequently, there is an absence of effective application of appropriate corporate governance codes in listed firms in Egypt.

Audit type has an insignificant impact on capital structure choices taken by Egyptian firms. This could be due to different legislations and cultural factors in Egypt. These factors may form how corporate governance mechanisms influence capital structure decisions. Accordingly, the corporate governance has a significant influence on the capital structure decisions of Egyptian companies.

Regarding the traditional determinants of capital structures such as a firms' size, profitability, growth, tangibility, corporate tax and non-debt tax shields, they have a significant impact on corporate capital structure. Firm size is negatively significantly correlated with the short term debt and total debt to asset. Profitability is found to be negatively significant with corporate leverage variables. These findings support the pecking order theory where firms use internal funds as a first priority, debt as a secondary priority, and equity as a last option in finance. Tangibility is found to be positive significantly associated to corporate leverage variables. The findings indicate that high- tangible companies tend to use high leverage to fund their investments more than low-tangible companies. Growth and corporate tax are found positively significant with the corporate leverage variables, which support the estimates of signaling and pecking order theories. Finally, non-debt tax shields is negatively significant with the short term debt and total debt to asset. Hence, it can be concluded that, Egyptian firms have shown the same relationship with what has been achieved in developed Western countries. The results of this study have political implications on Cairo Stock Exchange as an emerging economy. Shareholders and managers should take into account the capital structure and corporate governance during the investment decision.

The main contribution to the literature is that, rather than considering just one measure of capital structure, this study considers four different capital structure measures. To the best of our knowledge, although the relationship between corporate governance and capital structure has been widely researched in developed economies, few studies have been conducted to examine this problem in the business environment of emerging economies like Egypt.

It should be noted that there might be variables that influence the relationship between corporate governance and capital structure that have not been recognized in this study. Nevertheless, the specific factors/variables that have been used in this study have been used extensively in earlier studies of corporate governance and capital structure decisions.

\section{References}

Abad, D., Ballesta, J. P., \& Yagüe, J. (2017). Audit opinions and information asymmetry in the stock market, Accounting and Finance, 57(2), 565-595. https://doi.org/10.1111/acfi.12175

Abdoli, M., lashkary, M., \& Dehghani, M. (2012). Corporate Governance and Its Effect on the Corporate Financial Leverage. Journal of Basic and applied Scientific Research, 2(9), 8552-8560.

Abdul-Qadir, A. B., Yaroson, E. V., \& Abdu, M. (2015). Institutional Investors, Board Size and Capital Structure Decisions: Empirical Evidence from Non-Financial Firms in Nigeria. European Journal of Business and Management, 7(23), 82-90.

Abor, J. (2007). Corporate governance and financing decisions of Ghanaian listed firms. Corporate Governance: International Journal of Business in Society, 7(1), 83-92. https://doi.org/10.1108/14720700710727131

Abor, J., \& Biekpe N. (2005). What Determines the Capital Structure of Listed Firms in Ghana? The African Finance Journal, 7, 37-48.

Abor, J., \& Biekpe, N. (2007). Corporate governance, ownership structure and performance of SMES in Ghana: Implications for financing opportunities. Corporate Governance: International Journal of Business in 
Society, 7(3), 288-300. https://doi.org/10.1108/14720700710756562

Acaravci K. S. (2015). The determinants of capital structure: Evidence from the Turkish manufacturing sector, International Journal of Economics and Financial, 5(1), 158-171.

Agyei, A., \& Owusu, A. R. (2014). The effect of ownership structure and corporate governance on capital structure of Ghanaian listed manufacturing companies. International Journal of Academic Research in Accounting, Finance and Management Sciences, 4(1), 109-118. http://dx.doi.org/10.6007/IJARAFMS/v4-i1/547

Ajanthan, A. (2013). The determinants of capital structure: Evidence from hotel and restaurant companies in Srilanka. International Journal of Scientific and Research Publications, 3(6), 1-8.

Al- Najjar, B., \& Hussainey, K. (2011). Revisiting the capital structure puzzle: UK evidence. The Journal of Risk Finance, 12(4), 329-338. https://doi.org/10.1108/15265941111158505

Al- Najjar, B., \& Taylor, P. (2008). The relationship between capital structure, and ownership structure: New evidence from Jordanian panel data. Managerial Finance, 34(12), 919-933. https://doi.org/10.1108/03074350810915851

Al-Najjar, B. (2011). Empirical modelling of capital structure: Jordanian evidence. Journal of Emerging Market Finance, 10(1), 1-19. https://doi.org/10.1177/097265271101000101

Al-Najjar, B., \& Hussainey, K. (2009). The association between dividend payout and outside directorships. Journal of Applied Accounting Research, 10(1), 4-19. https://doi.org/10.1108/09675420910963360

Amarjit, G., Nahum, B., Harvinder, S. M., \& Charul, S. (2012). Corporate governance and capital structure of small business service firms in India. International Journal of Economics and Finance, 4(8), 83-92. http://dx.doi.org/10.5539/ijef.v4n8p83

Bauer, P. (2004). Determinants of capital structure: Empirical evidence from the Czech Republic. Czech. Journal of Economics and Finance, 54(1), 1-21.

Berger, P. G., Ofek, E., \& Yermack, D. L. (2012). Managerial entrenchment and capital structure decisions. The Journal of Finance, 52(4, 1411-1438. https://doi.org/10.1111/j.1540-6261.1997.tb01115.x

Bharath, S., Pasquariello, P., \& Wu, G. (2009). Does asymmetric information drive capital structure decisions? Review of Financial Studies, 22(8), 3211-3243. https://doi.org/10.1093/rfs/hhn076

Booth, L., Aivazian, V., Demirguc-Kunt, A., \& Maksmivoc, V. (2001). Capital structure in developing countries. Journal of Finance, 56(1), 87-130. https://doi.org/10.1111/0022-1082.00320

Brailsford, T. J., OIiver, B. R., \& Pua, S. L. H. (2002). On the relation between ownership structure and capital structure. Accounting and Finance, 42(1), 1-26. https://doi.org/10.1111/1467-629X.00001

Cespedes, J., González, M., \& Molina, A. C. (2010). Ownership and capital structure in Latin America. Journal of business research, 63(3), 248-254. https://doi.org/10.1016/j.jbusres.2009.03.010

Chakraborty, I. (2010). Capital structure in an emerging stock market: The case of India. Research in International Business and Finance, 24(3), 295-314. https://doi.org/10.1016/j.ribaf.2010.02.001

Chitiavi, M. S., Musiega, M. G., Alala, O. B., Musiega, D., \& Maokomba, C. O. (2013). Capital Structure and Corporate Governance practices. Evidence from Listed Non-Financial Firms on Nairobi Securities Exchange Kenya. Journal of Business and Management, 10(2), 8-16. https://doi.org/10.9790/487X-1020816

Coase, R. H. (1937). The Nature of the Firm Economical. New Series, 4(16), 386-405. https://doi.org/10.1111/j.1468-0335.1937.tb00002.x

DeAngelo, H., \& Masulis, R.W. (1980). Optimal capital structure under corporate and personal taxation. Journal of Financial Economics, 8(1), 3-29. https://doi.org/10.1016/0304-405X(80)90019-7

Deesomsak, R., Paudyal, K. \& Pescetto, G. (2004). The determinants of capital structure: Evidence from the Asia Pacific Region. Journal of Multinational Financial Management, 14(4), 387-405 https://doi.org/10.1016/j.mulfin.2004.03.001

Delcoure, N. (2007). The determinants of capital structure in transitional economies. International Review of Economics and Finance, 16(3), 400-415. https://doi.org/10.1016/j.iref.2005.03.005

Driffield, N., Mahambare, V., \& Pal, S. (2007). How does ownership structure affect capital structure firm value? 
Recent evidence from East Asia. Economics of Transition, 15(3), 535-573. https://doi.org/10.1111/j.1468-0351.2007.00291.x

Du, J., \& Dai, Y. (2005). Ultimate corporate ownership structures and capital structures: Evidence from East Asian economies. Corporate Governance: An International Review, 13(1), 60-71. https://doi.org/10.1111/j.1467-8683.2005.00403.x

Eriotis, N., Vasiliou, D., \& Ventoura-Neokosmidi, Z. (2007). How firm characteristics affect capital structure: an empirical study. Managerial Finance, 33(5), 321-331. https://doi.org/10.1108/03074350710739605

Fama, E.F. \& Jensen, M., (1983). Agency problem and residual claims. Journal of Law and Economics, 26, 327-349. https://doi.org/10.1086/467038

Friend, I., \& Lang, L. H.P, (1988). An empirical test of the impact of managerial self-interest on corporate capital structure. Journal of Finance, 43(2), 271-281. https://doi.org/10.1111/j.1540-6261.1988.tb03938.x

Ganiyu, Y. O., \& Abiodun B.Y. (2012). The impact of corporate governance on capital structure decision of Nigerian firms. Research Journal in Organizational Psychology and Educational Studies, 1(2), 121-128.

Ghazouani, T. (2013). The capital structure through the trade-off theory: Evidence from Tunisian firms. International Journal of Economics and Financial Issues, 3(3), 625-636.

Graham, J. R., \& Harvey, C. (2001). The theory and practice of corporate finance: evidence from the field. Journal of Financial Economics, 60(2), 187-243. https://doi.org/10.1016/S0304-405X(01)00044-7

Gwatidzo, T., \& Ojah, K. (2009). Corporate capital structure determinates - Evidence from five African countries. The African Finance Journal, 11(1), 1-23.

Harris, M., \& Raviv, A. (1991). The theory of capital structure. Journal of Finance, 46(1), 297-356. https://doi.org/10.1111/j.1540-6261.1991.tb03753.x

Hasan, A., \& Butt, S. A. (2009). Impact of ownership structure and corporate governance on capital structure of Pakistani listed companies. International Journal of Business and Management, 4(2), 50-57. http://dx.doi.org/10.5539/ijbm.v4n2p50

Homaifar, G., Zietz, J. \& Benkato, O. (1994). An empirical model of capital structure: some new evidence. Journal of Business Finance and Accounting, 21(1), 1-14. https://doi.org/10.1111/j.1468-5957.1994.tb00302.x

Hussainey, K., \& Aljifri, k. (2012). Corporate governance mechanisms and capital structure in UAE. Journal of Applied Accounting Research, 13(2), 145-160. https://doi.org/10.1108/09675421211254849

Jensen, M. C. (1986). Agency costs of free cash flow, corporate finance, and takeovers. The American Economic Review, 76(2), 323-329.

Jensen, M., \& Meckling, W. (1976). Theory of the firm: managerial behavior, agency costs and capital structure. Journal of Financial Economics, 3(4), 305-360. https://doi.org/10.1016/0304-405X(76)90026-X

Koch, P. D., \& Shenoy, C. (1999). The information content of dividend and capital structure policies. Financial Management, 28(4), 16-35. https://doi.org/10.2307/3666301

Kochhar, R. (1996). Explaining firm capital structure: the role of agency theory vs. transaction cost economies. $\begin{array}{llll}\text { Strategic } & \text { Management }\end{array}$ https://doi.org/10.1002/(SICI)1097-0266(199611)17:9<713::AID-SMJ844>3.0.CO;2-9

Kuo, H. C., Wang, L. H., \& Liu, H. W. (2012). Corporate governance and capital structure: Evidence from Taiwan SMEs. Review of Economics \& Finance, 2, 43-58.

Maghyereh, A. (2005). Dynamic capital structure: Evidence from the small developing country of Jordan. Journal of Economics and Management, 13(1), 1-32.

Masood A., (2014). Relationship between ownership structure and capital structure: A case of manufacturing sector of Pakistan. Journal of Basic and Applied Scientific Research, 4(2), 180-188.

Michaely, R. and Vincent, C. (2012). Do institutional investors influence capital structure decisions? Johnson School Research Paper Series.

Modigliani, F., \& Miller, M. H. (1958). The cost of capital, corporate finance, and the theory of investment. American Economic Review, 48(3), 261-297.

Modigliani, F., \& Miller, M. H. (1963). Corporate income taxes and the cost of capital. The American Economic Review, 53(3), 433-443. 
Myers, S. C. (1977). Determinants of corporate borrowing. Journal of Financial Economics, 5(2), 147-175. https://doi.org/10.1016/0304-405X(77)90015-0

Myers, S. C. (1984). The capital structure puzzle. The Journal of Finance, 39(3), 575-592. https://doi.org/10.1111/j.1540-6261.1984.tb03646.x

Ngugi, R. (2008). Capital financing behavior: Evidence from firms listed on the Nairobi stock exchange. The European Journal of Finance, 14(7), 609-624. https://doi.org/10.1080/13518470802042245

Purag, M. B., \& Abdullah, A. B. (2016). Corporate governance and capital structure of Malaysian family-owned companies. Journal of Business and Retail Management Research (JBRMR), 11(1), 18-30.

Rocca, M. L. (2007). The influence of corporate governance on the relation between capital structure and value. Corporate Governance: International Journal of Business in Society, 7(3), 312-325. https://doi.org/10.1108/14720700710756580

Ross, S. A. (1977). The determination of financial structure: The incentive-signaling approach. The Bell Journal of Economics, 8(1), 23-40. https://doi.org/10.2307/3003485

Ruan, W., Tian, G., \& Ma, S. (2011). Managerial ownership, capital structure and firm value: Evidence from China's civilian-run firms. Australasian Accounting Business and Finance, 5(3), 73-92.

Sheikh, N. A., \& Wang, Z. (2012). Effects of corporate governance on capital structure: empirical evidence from Pakistan. Corporate Governance: International Journal of Business in Society, 12(5), 629-641. https://doi.org/10.1108/14720701211275569

Smith, M. (1996). Shareholder activism by institutional investors: Evidence from CalPERS. Journal of Finance, 5l(1), 227-252. https://doi.org/10.1111/j.1540-6261.1996.tb05208.x

Tomak, S. (2013). The impact of overconfidence on capital structure in Turkey. International Journal of Economics and Financial Issues, 3(2), 512-518.

Uwuigbe, O. R. (2013). The effects of board size and CEO duality on firms' capital structure: A study of selected listed firms in Nigeria. Asian Economic and Financial Review, 3(8), 1033-1043.

Wahab, S. N. A., \& Ramli, N. A. (2014). The determinants of capital structure: An empirical investigation of Malaysian listed government linked companies. International Journal of Economics and Financial Issues, 4(4), 930-945.

Wahba, H. (2014). Capital structure, managerial ownership and firm performance: Evidence from Egypt. Journal of Management \& Governance, 18(4), 1041-1061. https://doi.org/10.1007/s10997-013-9271-8

Yaseen, H., \& Al-Amarneh, A. (2015). Corporate Governance and the Financial Leverage: Evidence from Jordan. Research Journal of Finance and Accounting, 6(12), 180-187.

Zerriaa, M., \& Noubbigh, H. (2015). Determinants of capital structure: Evidence from Tunisian listed firms. International Journal of Business and Management, 10(9), 121-135. http://dx.doi.org/10.5539/ijbm.v10n9p121

\section{Copyrights}

Copyright for this article is retained by the author(s), with first publication rights granted to the journal.

This is an open-access article distributed under the terms and conditions of the Creative Commons Attribution license (http://creativecommons.org/licenses/by/4.0/). 